\title{
GEOECOLOGY
}

\section{Ecological Network Model in Shahdagh National Park}

\author{
E.A. Jabrayilov $\bowtie$ \\ Institute of Geography, Azerbaijan National Academy of Sciences, Azerbaijan \\ (115, H. Javid Ave., Baku, AZ1143)
}

\begin{abstract}
The purpose of this article is to explore the possibility of creating an ecological network that includes core areas, buffer zones, ecological corridors, and restoration areas in the section of the Shamakhi district of the Shahdagh National Park (Azerbaijan).

Materials and methods. As materials, we used vector and raster data, as well as literature materials to determine and analyse the elements of an ecological network. Operations were performed by using ArcGIS 10.8 and ERDAS Imagine software. During the field research, observations were made in order to match the elements of the ecological network with the cameral study.

Results. In the article, protected natural areas are presented as the core areas and the surrounding areas as buffer zones under the relevant legislation. Riverbeds, mountain passes, trails, and forests which should be planted in the areas we offer, were considered as main factors during the construction of ecological corridors in the national park and the buffer zones. In this case, "least-cost" modelling was applied and ecological corridors were designated to ensure connectivity between core areas. As a result, the optimal ecological network model for the study area has been developed and mapped in the article.

Conclusion. The high growth rate of consumption of natural resources led to the loss of biodiversity in the last decades. At present, it is important to take the necessary measures, and connectivity of ecosystems and natural complexes play an important role in sustainability. The presented model in the study can help to conserve biodiversity, reduce anthropogenic impacts, eliminate environmental barriers, and develop appropriate forms of land use.
\end{abstract}

Key words: ecological network, ecological corridors, buffer zones, ecosystems.

For citation: Jabrayilov E.A. Ecological Network Model in Shahdagh National Park. Vestnik Voronezskogo gosudarstvennogo universiteta. Seria: Geografia. Geoekologia, 2021, no. 2, pp. 61-69. (In Russ.). DOI: https://doi.org/10.17308/geo.2021.2/3449

\section{INTRODUCTION}

The high rate of growth using of natural resources by the human in the last century have seriously negatively affected ecosystems and led to the biodiversity loss [3]. Strengthening ecological coherence and sustainability as a prerequisite for biodiversity conservation and sustainable development is currently increasing its relevance. Ecological networks have been developing for over 40 years as a model in order to preserve the integrity of environmental processes. Since the 1980 s, several national environmental programs have been developed in Central and Eastern Europe based on the concept of a "polarized landscape" [23] by Russian geographer Boris Rodoman.In most other regions of Europe, the ecological network model is based mainly on MacArthur and Wilson's Theory

(C) Jabrayilov E.A., 2021

\ Jabrayilov Emil Akif oghlu, e-mail: emil.jabrayilov@gmail.com

(c) (i) The content is available under Creative Commons Attribution 4.0 License. of Island Biogeography [18]. Since the 1990s, regional and national programs aimed at expanding and coordinating protected areas have been accelerated in the countries of Western Europe, North America, Latin America, and Australia.

Generally, these approaches, which are classified as ecological networks share two common goals: preserving ecosystems to facilitate the protection of species and the environment and reducing the impact of human activities on biodiversity by promoting sustainable use of natural resources or increasing the value of managed landscapes. [4]. Ecological networks represent a general approach to how they can be applied at the local level by distributing specific functions in various fields, depending on their environmental value and their potential [5]. Ecological networks promote the sustainability of natural resources, encouraging connectivity between

Вестник ВГУ, Серия: География. Геоэкология, 2021, № 2, 61-69 
land use objectives and biodiversity conservation [21]. Globally, various ecological networks are being developed on the regional scale $[3,5,16]$.

Protected areas are essential for protecting biodiversity and supporting environmental processes [17, 22]. It is highly advisable to plan ecological networks in protected areas that play a special role in maintaining environmental integrity. In practice, due to different land ownership and management forms, ecological networks can cover some or all of the protected areas. The differentiation of protected areas in terms of type, purpose, and use requires that management mechanisms should be organized according to local conditions.

The Shahdagh National Park, which we studied in the article, is the largest national park in the South Caucasus and covers mainly the middle and high mountains of the Greater Caucasus in Azerbaijan. The current territory of the national park, created in 2006, is 130,508.1 hectares. The main goals of the establishment of the National Park are restoration and management of mountain ecosystems, protection of endemic and endangered species, carrying out scientific research, environmental education of the population, development of ecotourism, and so on. The national park, which borders the Russian Federation from the north, covers the mountainous parts of six administrative regions of Azerbaijan - Oghuz, Gabala, Ismayilli, Shamakhi, Guba, and Gusar. There are two main highways from the capital towards the national park. One of them is in the direction of Baku, Shamakhi, Ismayilli, Gabala and Oghuz regions, and another one is towards Baku, Guba, and Gusar regions.
Defining and establishing an ecological network in the park is essential for the development of the national park, including the protection of the environment and biodiversity, reducing the impact of human activities, and ultimately ensuring sustainable development of ecosystems.

\section{MATERIALS AND METHODS}

Study area. The study area is part of the Shahdagh National Park within Shamakhi District and its surrounding areas (Fig. 1). Coordinates: $40^{\circ} 41^{\prime}-40^{\circ} 50^{\prime} \mathrm{N}$; $48^{\circ} 28^{\prime}-48^{\circ} 42^{\prime} \mathrm{E}$. The designated buffer zone of the National Park includes 14 villages and 1 settlement-type administrative unit. The creation of this protected area dates back to 1968. The Pirgulu State Nature Reserve, established at that time, played an exceptional role in the protection of mountain landscapes, vegetation, soils, and valuable fauna. Since 2006, the nature reserve has been part of the Shahdagh National Park.

Methodological approach. In the research, the ecological network model was used as a conceptual model [3]. In the course of the study, literature materials, a digital elevation model (DEM), vector and raster data were used and field observations were carried out. During the field research, observations were made in terms of the compatibility of the elements of the ecological network with the cameral works. Based on DEM [10] with a resolution of $12,5 \mathrm{~m}$, the altitude zones of the area were determined, and the slope indicators were calculated. As raster data, topographic maps, satellite images (SENTINEL-2B Multi-Spectral Instrument) were used to obtain information about the park's location, boundaries,

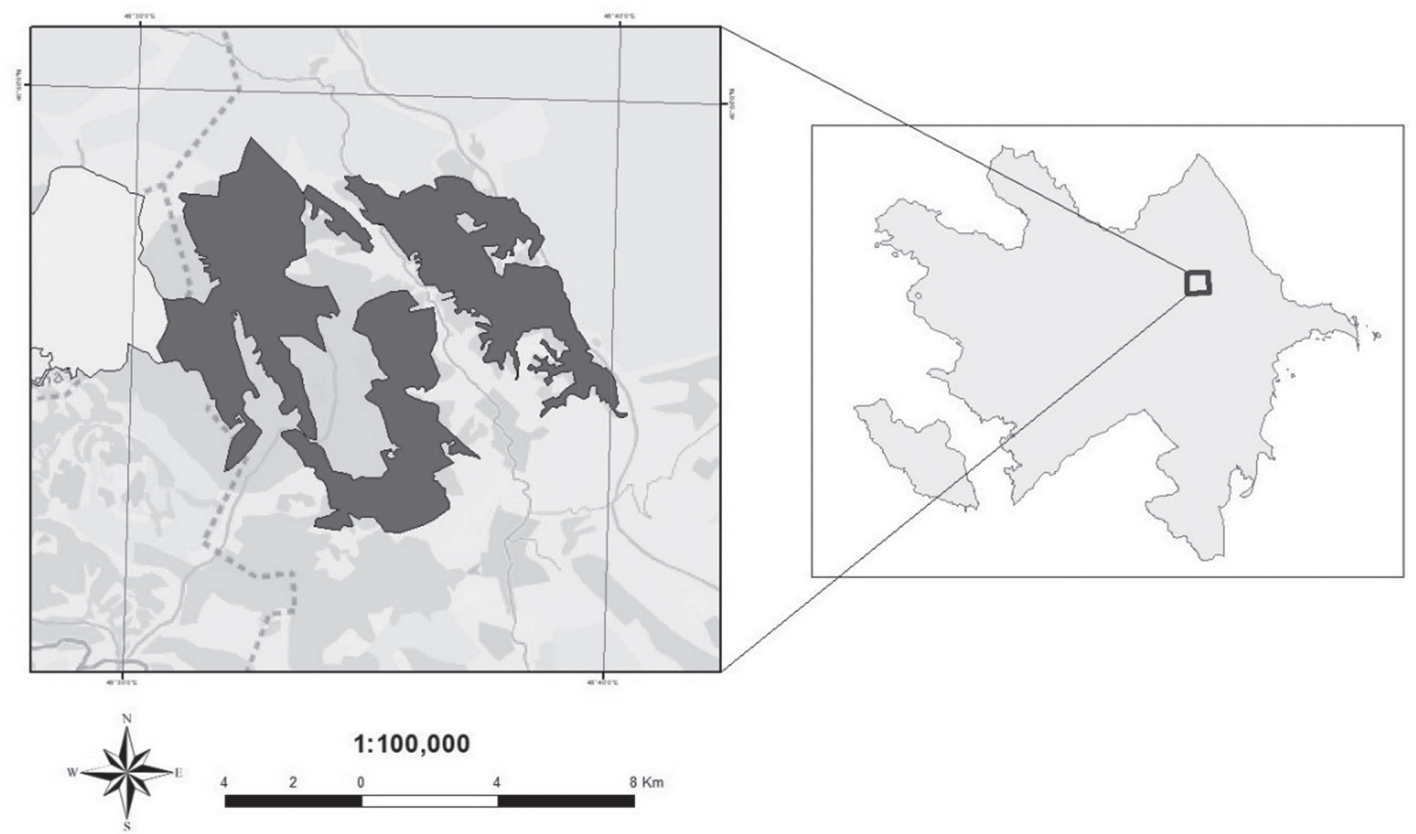

Fig. 1. Location map of study area - Shamakhi section of Shahdagh National Park

[Puc. 1. Карта расположения исследуемой территории - Шамахинский участок Шахдагского национального парка] 
infrastructure, as well as to assess the productivity of biotopes (NDVI) at the spectral level. Vector data were included during the vectorization of ecological network elements. Operations that were based on a digital elevation model and vectorization have been developed in ArcGIS 10 software. ERDAS Imagine 15 was used for spectral analysis of the satellite images.

\section{RESULTS AND DISCUSSION}

Natural resources. As in other sections of the Shahdagh National Park, the study area which is included in the Shamakhi region has a complicated mountainous terrain. The mountainous landscape is predominant in the area and the absolute height varies between 500$2200 \mathrm{~m}$ above sea level. The slope indicators vary depending on the characteristics of the relief. As the altitude increases in the western direction, the inclination also increases (up to 76 degrees). The lowest slope values (up to 10 degrees) correspond to riverbeds (Fig. 2).

The main mountain systems are Mount Pirqulu, Girkhbulag, Gart, Alifdagh, and Jangi. Aghsuchay river and its tributaries Kirkhbulag, Avakhil, Marmarakhar, Sis and others, and Pirsaatchay river with its Janut (Mustafalichay) tributary is the base of the river network in the area. The area is more widespread with oak-hornbeam, beech-hornbeam, beech-oak forests at the middle uplands, and forest-steppe, steppe, and subalpine meadows at the low highlands [19]. According to the land cover classification of the satellite image, approximately, natural forests cover $30,5 \%$ of the study area, sparse forest $9,5 \%$, agricultural lands $31,6 \%$, living and open areas $25,9 \%$, and water bodies $2,6 \%$.

The mountainous relief of the area is one of the key factors affecting climate formation. Here the temperature and precipitation indicators vary depending on the altitude. The average annual temperature in the Pirgulu stationary is $8^{\circ} \mathrm{C}$. The average temperatures in January and July are $-4^{\circ} \mathrm{C}$ and $19,7^{\circ} \mathrm{C}$, respectively. Annual precipitation varies between 600 and $900 \mathrm{~mm}$ depending on the altitude. Spring and autumn precipitation become more intensive and stronger. July and August are the driest periods. Heavy rains occur frequently and cause the soil to wash and eroded $[14,15]$.

The relief and climatic conditions of the national park also contributed to the enrichment of biodiversity. Iberian and eastern oak, eastern beech, Caucasian hornbeam, ash-trees, maple and Taxus, and types of shrubs, including hawthorn, medlar, blackberries, rose hips, etc. predominate in the forests. Among the species of animals - a brown bear, deer, wild boar, wolf, eagle, fox, badger, jackal, rabbit; poultry, pheasants, quail, woodpecker, etc. spread here.

The productivity of biotopes in the study area was determined based on images recorded from SENTINEL-2B Multi-Spectral Instrument (MSI) on 17.08.2019 and 24.01.2019. Band 4 (Red) and Band 8 (NIR) spectral data with a resolution of $10 \mathrm{~m}$ [11] were used for this purpose. NDVI was calculated using the existing methodology, NIR-Red / NIR-Red formula $[6,13]$. Based on the recorded seasonal changes, it

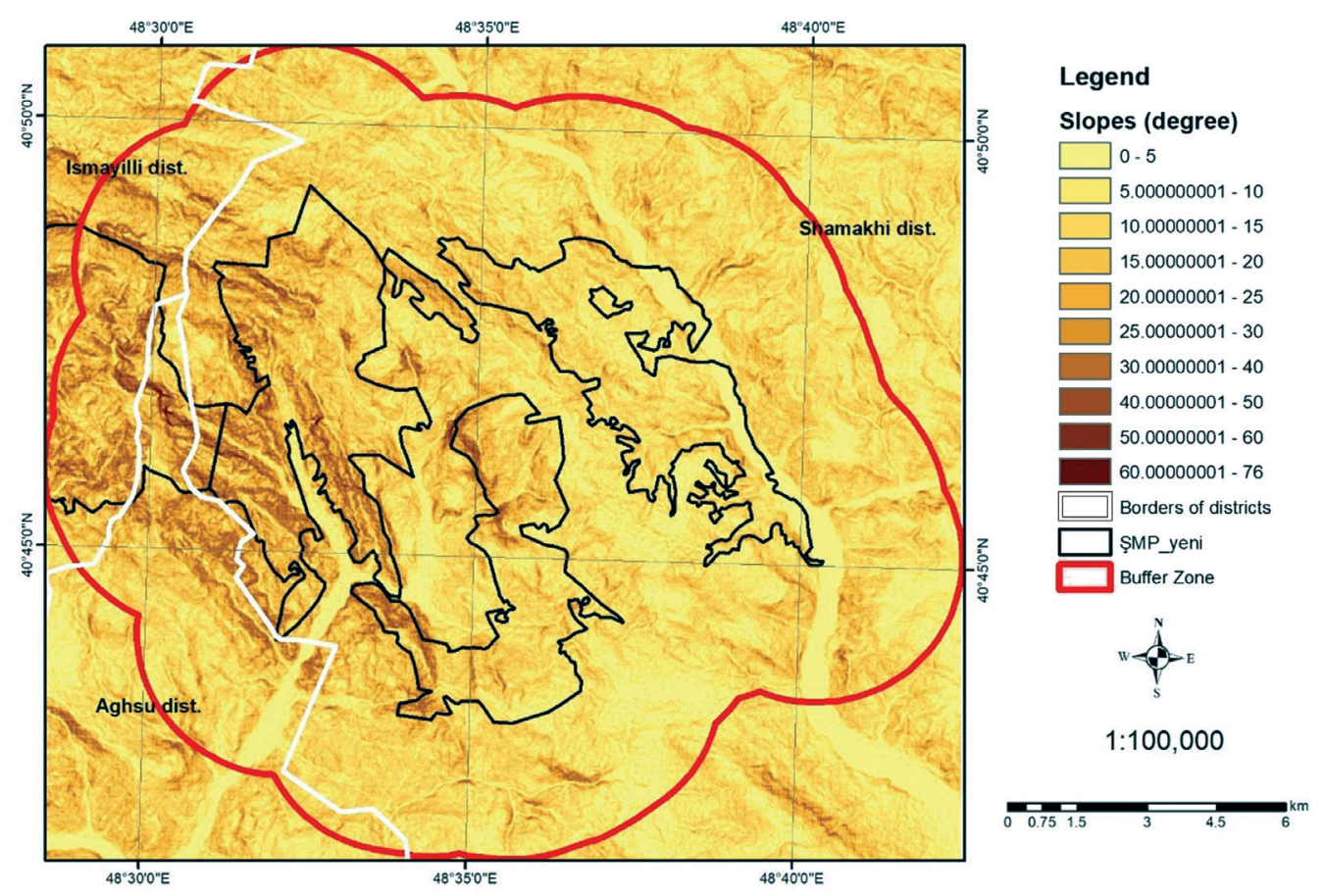

Fig. 2. Slope indicators of the study area

[Puc. 2. Показатели наклона исследуемой территории] 
was determined that NDVI is getting higher during the summer season with an increase in green biomass. Field indices were calculated for both seasons. Thus, in summer, more than $50 \%$ of the area corresponds to the index of $0,4-0,85$. However, in winter, most of the areas $(93,8 \%)$ correspond to the $0-0,4$ index. The highest NDVI value of $0,6-0,85$ is observed in 13,044 ha in summer and only 21 ha in winter (Table 1 ).
Elements of the ecological network in the national park. The design of ecological networks allows for their implementation in land use policy and landscape planning as well $[2,16]$. Ecological network might be as a reference for the evaluation of regional development plans and might be developed for the whole region in the future.

Among the elements of the ecological network, $19,6 \%$ of the study area are core areas, $64,7 \%$ are

Changes in summer and winter seasons in the area's biotopes

[Таблица 1. Изменения летнего и зимнего сезонов в биотопах района]

\begin{tabular}{|c|c|c|c|c|}
\hline \multirow{2}{*}{ NDVI } & $\begin{array}{c}\text { Summer season (17.08.2019) / летний } \\
\text { сезон (17.08.2019) }\end{array}$ & $\begin{array}{c}\text { Winter season (24.01.2019) / зимний } \\
\text { сезон (24.01.2019) }\end{array}$ \\
\cline { 2 - 5 } & $h a$ & $\%$ & $h a$ & $\%$ \\
\hline$-0.3-0$ & 8 & 0,02 & 1355 & 3,9 \\
\hline $0-0,2$ & 5146 & 14,8 & 18414 & 52,9 \\
\hline $0.2-0,4$ & 9565 & 27,5 & 14246 & 40,9 \\
\hline $0.4-0,6$ & 7063 & 20,3 & 790 & 2,3 \\
\hline $0.6-0,85$ & 13044 & 37,4 & 21 & 0,06 \\
\hline
\end{tabular}

buffer zones, $8,5 \%$ are restoration areas and $7,2 \%$ are ecological corridors (Table 2).

Core areas are landscapes, species, and ecosystems that are protected and have particular value. These areas have been identified by landscape diversity, existing ecosystems, and surface cover configurations. The development of these parameters also leads to an increase in species. The larger the area is and the greater the environmental conditions are, the lower the risk of species depletion. A wide range of core areas results in better conservation of biodiversity in the region, leading to higher migration activities of the species.

The area covered by the national park is designated as a core area. The total area of the core area is 5896 ha, most of which is covered by oak-hornbeam, beech-hornbeam, beech-oak forest ecosystems of low and middle uplands (Table 2). As a protected area, human activities in core areas are regulated by relevant legislative acts. Since the territory has the status of a national park, following the regulation there is possible to create zones as follows to ensure the functioning of the national park: zones where a special legal protection regime is applied, tourism and recreation zones, service zones for tourists and others, economic and production zones. The distribution of the territory of the National Park by zones of protection with special regimes is defined bythe Cabinet of Ministers of the Republic of Azerbaijan based on the presentation of the Ministry of Ecology and Natural Resources of Azerbaijan.

Ecological corridors, as key elements of ecological networks, play an extremely important role in facilitating the migration of animals and plants in specially protected areas. In today's rapid popula- tion growth, ecological corridors are essential for the long-term survival and sustainable development of biodiversity [7].

Increasing human exposure to nature also leads to an increase in the number of depleted species. For one reason or another, the migration process is disrupted, which leads to the depletion of species of animals and plants that correspond to local conditions, and the inability to return to the process at a later stage. This tendency can be effectively prevented by protecting nature and restoring ecological corridors.

During the construction of the ecological corridors in the Shahdagh National Park, riverbeds, intermountain depressions, mountain passes, trails, and forests, which should be planted in the proposed areas, were taken as a basis. Physiognomically, all three types of ecological corridors [9] were applied in the study area, taking into account the presence of lines, steppe-stones, and landscapes. Line corridors have been identified along the 200 $\mathrm{m}$ width and $72 \mathrm{~km}$ length of the river beds. The type of stepping-stone corridors facilitates the establishment of interconnection between the core areas through planting trees and greenery. For this purpose, this type of ecological corridor has been identified within different directions. The landscape type of ecological corridors has been proposed for the organization of communication between core areas and linear corridors near the Sis and Kaleybugurt villages, covering relatively large areas.

Ecological corridors play a role in linking of species' habitats and restoring natural biological migration. Since the selection of species as a target during corridor identification is required, we have focused on mammalian species such as brown bears, roe 
deers, wild boars, badgers and rabbits living in the park. Because these animals prefer moving in the forest and vegetated green areas, their lifestyle is also considered in the study. The habitats of such animals are suitable sites for the development of ecological processes, with the role of migration "sources" [8].

During the determination of ecological corridors, least-cost modelling was applied for evaluation of the connectivity of the landscapes $[1,12]$. First, the "Cost Distance" function was applied in ArcGIS 10.8, and the value of the radial displacement between the nuclear areas was calculated taking into account the slope indicators. At the next step, least-cost paths, which are connecting the core areas, were identified with the CostPath function. With this method, several optimal directions of animals' movement have been selected, and at the same time, the locations of the stepping stone corridors between the core areas along these paths have been identified (Fig. 3). In addition, it is possible to increase such paths by almost the same method.

Buffer zones are areas that are responsible for maintaining and protecting the core areas or are particularly important for keeping balance in geosystems. [21]. Functionally it is divided into protective and geosystem buffer zones. Buffer zones serve to improve ecosystems, preserve and enhance the geosystem balance, and neutralize the environmental impacts between agricultural and protected areas in the ecological network.

The buffer zone of the study area was set at 3000 meters along the border of the core area with the admission of the relevant article of the Law of the Republic of Azerbaijan "On Specially Protected Natural Areas and Objects". The total area is 19400 hectares. The main ecosystems are mountain-forests, mountain meadow, forest-steppe, subalpine meadows, and seliteb zones. This zone includes 14 villages and 1 settlement. In the ecosystems located here, it is only possible to engage in economic and other activities in the manner prescribed by the legislation. According to this law, scientific-research activities, environmental monitoring and control of ecosystem changes, fire protection and maintenance of forest areas, use of land for economic purposes, as well as grasslands and pastures, restoration of biodiversity and natural ecosystems, recreational purposes are types of activities with permitted inside of buffer zones. But otherwise, construction of new settlements, placement, and operation of enterprises that create environmental hazards, including chemical, nuclear energy, and metallurgical industries, geological exploration, extraction and processing of minerals, use of forests, using of agrochemicals and pesticides, the introduction of species not compatible with local fauna and flora, and activities that violate the hydrological regime of the area and affect the soil fertility are prohibited.

Restoration areas are created for the restoration of biological or geomorphological conditions of the territory. Typically, such zones are areas that are not profitable, despite the various efforts and methods used, or have greatly deteriorated as a result of anthropogenic impacts. Therefore, the restoration is inevitable to the recovery of such soils and saving the ecosystems. Such areas may become core areas or buffer zones at the later stages.

Several problems or questions may arise during the design of the restoration areas. One of the problems may be against the interest of stakeholders in the selection of such areas and in making decisions for the common good. Coordination of rehabilitation activities, effective use of resources for positive results, and decision-making based on the advice of scientific researchers and experts during implementation are basic terms. These conditions have been taken into account when determining the restoration areas around the na-

Ecological network elements and ecosystems in the study area

Table 2

[Таблииа 2. Элементы экологической сети и экосистемы в районе исследования]

\begin{tabular}{|c|c|c|c|}
\hline \multirow{2}{*}{$\begin{array}{l}\text { Network elements / } \\
\text { Элементы сети }\end{array}$} & \multicolumn{2}{|c|}{ Area / Площадь } & \multirow{2}{*}{ Ecosystems / Экосистемы } \\
\hline & ha & $\%$ & \\
\hline Core area & 5896 & 19.6 & $\begin{array}{l}\text { Oak-hornbeam, beech-hornbeam, beech-oak forests } \\
\text { ecosystems of low and medium highlands }\end{array}$ \\
\hline $\begin{array}{l}\text { Ecological corridors: } \\
\text { linear } \\
\text { stepping-stone } \\
\text { landscape }\end{array}$ & $\begin{array}{c}1437 \\
69 \\
648\end{array}$ & $\begin{array}{l}4.8 \\
0.2 \\
2.2\end{array}$ & Mountain forests, mountain meadows, river ecosystems, \\
\hline Buffer zone & 19400 & 64.7 & $\begin{array}{l}\text { Mountain forests, mountain meadows, forest-steppe, } \\
\text { subalpine meadows, seliteb zones }\end{array}$ \\
\hline Restoration areas & 2550 & 8.5 & $\begin{array}{l}\text { Mountain forests, mountain meadows, forest-steppe, } \\
\text { mountain steppe }\end{array}$ \\
\hline
\end{tabular}

Вестник ВГУ, Серия: География. Геоэкология, 2021, № 2, 61-69 




Fig. 3. Ecological network model of the study area

[Puc. 3. Экологическая сетевая модель исследуемой территории]

tional park in the study. Such areas have been identified along the northern and southern boundaries and within the interior structure of the national park, especially in areas where natural ecosystems are essential for restoration (Fig. 3).Over time and the recovery process, showing positive results, the boundaries of the national park can be expanded at the expense of such areas.

Proposals. Ecological networks as a model represent an ecosystem approach that promotes the conservation of biodiversity and the sustainable use of natural resources. The basis of this approach is that economic development is not possible without the effective management of ecosystems for the benefit of society [24]. The involvement of various sectors of the economy and society in the management of ecosystems is an important factor for the implementation of the approach. Proposals for the study area to address such issues are as follows.

1. The management of ecosystems, including all elements of the ecological network, should be centralized and the impact of adjacent ecosystems should be taken into account.

2. Reduce economic activity, which negatively affects biodiversity in the development of ecosystem management programs, and promote the conservation and sustainable use of biodiversity.
3. To achieve the integrity of the ecological network, long-term goals should be set, and scientific approaches, knowledge of local communities and all forms of information should be taken into account.

4. Measures aimed at the protection and sustainable use of natural complexes require a broader and more comprehensive approach. Therefore, there is a need to develop additional activities and ecosystem services in residential areas. Fruit and its processing, expanding beekeeping, collecting medicinal herbs, selling local crafts, handicrafts, and stimulating activities for local businesspersons will lead to improve living standards and at the same time protecting biodiversity.

5. During the implementation and execution of this approach, scientific institutions such as Geography, Zoology, and Botany; the relevant executive government authorities, Ministry of Ecology and Natural Resources, as well as environmentally-oriented public associations, NGOs, and local businesspersons, stakeholders should be actively involved to the programs.

\section{CONCLUSION}

The ecological network model was analyzed in the study area, selected as a pilot in Azerbaijan. Core areas and buffer zones were determined following the legislation, and ecological corridor types and resto- 


\section{Ecological Network Model in Shahdagh National Park}

ration areas have been identified taking into account natural conditions in this study. For the network model, a map of the study area was developed, and the area of each network element was calculated within the corresponding ecosystems.

The productivity of biotopes in the area was calculated based on NDVI, and seasonal changes for the summer and winter months were identified. It was revealed that most of the area of green biomass corresponds to the index of $0,6-0,85$ in summer and $0-0,4$ in the winter season.

It became clear that the theoretical part of the research, connectivity of ecosystems and natural habitats play an important role in sustainability. Based on the slope indicators of the relief, a least-cost model was applied and ecological corridors connecting core areas were identified for the study area.

Relevant legislation and strategic documents should be adopted and programs should be developed for the inclusion of ecological networks in public policy at the national level. Since this approach does not require large financial resources, it is advisable to apply it in the future to the whole country.

The ecological network model presented in the article can help to conserve biodiversity, reduce anthropogenic impacts, eliminate environmental barriers, and promote appropriate forms of land use. Such connection analysis is not really the final solution, but the starting point. However, the more sophisticated optimum configuration of the ecological network to promote regional sustainable development can be determined by the transdisciplinary approach in future research.

\section{REFERENCES}

1. Adriaensen F., Chardon J.P., De Blust G., Swinnen E., Villalba S., \& Gulinck H., et al. The application of «least cost» modelling as a functional landscape model. Landscape and Urban Planning, 2003, 64(4), pp. 233-247. DOI: 10.1016/S0169-2046(02)00242-6.

2. Bennett A.F. Linkages in the landscape. The role of corridors and connectivity in wildlife conservation. IUCN, Gland, Switzerland and Cambridge, 1999, UK. x+254 pp.

3. Bennett G. and Mulongoy K.J. Review of Experience with Ecological Networks, Corridors and Buffer Zones. Secretariat of the Convention on Biological Diversity, Montreal, Technical Series, 2006, no. 23, 100 p.

4. Bennett G. and Wit P. The Development and Application of Ecological Networks: a Review of Proposals, Plans and Programmes. Amsterdam: AIDEnvironment, 2001. $137 \mathrm{p}$.

5. Bennett G. Integrating Biodiversity Conservation and Sustainable Use: Lessons Learned From Ecological Networks. IUCN, Gland, Switzerland, and Cambridge, 2004, UK. vi +55 pp.

Вестник ВГУ, Серия: География. Геоэкология, 2021, № 2, 61-69
6. Carlson T.N. and Ripley D.A. On the Relation between NDVI, Fractional Vegetation Cover, and Leaf Area Index. Remote Sensing of Environment, 1997, 62 (3): pp. 241-252. DOI: 10.1016/S0034-4257(97)00104-1.

7. Chang S.C., Tu C.J. \& Chen H.Y. Ecological corridor in the urban area: case study in Kaohsiung City, Taiwan. Practice Periodical of Hazardous, Toxic, and Radioactive Waste Management, 2010, 14 (1), pp. 76-88. DOI: 10.1061/(ASCE)HZ.1944-8376.0000018

8. Chen C.D., Meurk D.C., Ignatieva E.M., Stewart H.G. \& Wu S.J. Identifying and evaluating functional connectivity for building urban ecological networks. Acta Ecologica Sinica, 2015, 35 (19), pp. 18-35. DOI : 10.5846/ stxb201402160263

9. Climenco V., Trombitki I., Andreev A. The Ecological Network: A way to the nature conservation in Moldova. BIOTICA-Ecological Society, Moldova, 2002.

10. Dataset: JAXA/METI ALOS PALSAR L1.0 (2007). Accessed through NASA's Alaska Satellite Facility Distributed Active Archive Center (accessed: Aug 05, 2020).

11. Drusch M., Del Bello U., Carlier S., Colin O., Fernandez V., Gascon F., ... \& Bargellini P. Sentinel-2: ESA's optical high-resolution mission for GMES operational services. Remote sensing of Environment, 2012, 120, pp. 2536. DOI: $10.1016 /$ j.rse.2011.11.026.

12. Gurrutxaga M, Lozano P.J., del Barrio G. GISbased approach for incorporating the connectivity of ecological networks into regional planning. Journal for Nature Conservation, 2010, 18 (4): pp. 318-326. DOI: 10.1016/j. jnc.2010.01.005.

13. Gusev A.P. NDVI Changes as an Indicator of the Dynamics of the Ecological State ofLandscapes (on the Example of the Eastern Part of the Polessie Province). Proceedings of VSU, Series: Geography. Geoecology, 2020, no. 1, pp. 101-107. DOI: 10.17308/geo.2020.1/2667 (In Russ.).

14. Hajiyev G.A., Rahimov V.A. Climate characteristics of administrative regions of the Azerbaijan SSR. Baku, 1977. 270 p. (In Az.).

15. Ibrahimov T. National parks of Azerbaijan. Baku, 2015. 336 p. (In Az.).

16. Jongman R.H.G., Kulvik M., \& Kristiansen I. European ecological networks and greenways. Landscape and Urban Planning, 2004, 68 (2-3), pp. 305-319. DOI: 10.1016/S0169-2046(03)00163-4.

17. Lee T.M., Jetz W. Future battlegrounds for conservation under global change. Proceedings of the Royal Society B: Biological Sciences, 275 (1640), pp. 1261-1270. DOI: $10.1098 / \mathrm{rspb} .2007 .1732$

18. MacArthur R.H. and Wilson E.O. The Theory of Island Biogeography. Princeton University Press, 1967, vol.1. $215 \mathrm{p}$.

19. Mammadov G.Sh., Khalilov M.Y. Forests of Azerbaijan. 2002, Baku, 472 p. (In Az.)

20. Martino D. Buffer Zones around Protected Areas: A Brief Literature Review. Electron. Green Journal, 2001, 1 (15), pp. 1-20.

21. Opdam P., Steingrover E.G., \& van Rooij S.A.M. Ecological networks: A spatial concept for multi-actor 
planning of sustainable landscapes. Landscape and Urban Planning, 2006, 75 (3-4), pp. 322-332. DOI: 10.1016/j.landurbplan.2005.02.015.

22. Pressey R.L., Cabeza M., Watts M.E., Cowling R.M., Wilson K.A. Conservation planning in a changing world. Trends in ecology \& evolution, 2007, 22 (11), pp. 583-592. DOI: 10.1016/j.tree.2007.10.001.

23. Rodoman B.B. Landscape Polarization as a Means of Biosphere and Recreational Resources Conservation. Resources, Environment, Settlement, 1974, Nauka, pp. 150-162. (In Russ.).
24. Simenova V., Bos E., Jongman R., Zingstra H. Implementation of ecological networks in different socio-economic contexts. Guiding principles based on experiences in Central and Eastern Europe. Wageningen, Alterra, 2009. 117 p.

\section{CONFLICT OF INTERESTS}

The author declare no information of obvious and potential conflicts of interest related to the publication of this article.

Received: 01.03.2020

Accepted: 28.05.2021

\title{
ГЕОЭКОЛОГИЯ
}

\author{
УДК $502+911$ \\ DOI: https://doi.org/10.17308/geo.2021.2/3449
}

ISSN 1609-0683

\section{Модель экологической сети в Шахдагском национальном парке}

\author{
Э. А. Джабраилов ${ }^{\square}$ \\ Институт Географии Наииональной Академии Наук Азербайджана, Азербайджан \\ (AZ1143, г. Баку, пр. Г. Джавида, 115)
}

\begin{abstract}
Аннотация: Целью данной статьи является изучение возможности создания экологической сети, включающей основные территории, буферные зоны, экологические коридоры и восстановительные зоны на участке Шемахинского района Шахдагского национального парка.

Maтериалы и методы. В качестве материалов использованы векторные и растровые данные, а также литературные материалы для определения и анализа элементов экологической сети. Операции выполнялись с использованием программного обеспечения ArcGIS 10.8 и ERDAS Imagine. В ходе полевых исследований проводились наблюдения с целью сопоставления элементов экологической сети с камеральным исследованием.

Результаты. В статье охраняемые природные территории представлены как основные территории, а прилегающие территории - как буферные зоны, в соответствии с действующим законодательством. Русла рек, горные перевалы, тропы и леса, которые должны быть засажены на предлагаемых нами территориях, были учтены как основные факторы при строительстве экологических коридоров в национальном парке и буферных зонах. В этом случае было применено "least-cost" моделирование и определены экологические коридоры для обеспечения связи между основными территориями. В результате в статье была разработана и нанесена на карту оптимальная модель экологической сети для исследуемой территории.

Bblвoдbl. Высокие темпы роста потребления природных ресурсов привели к утрате биоразнообразия в последние десятилетия. В настоящее время важно принять необходимые природоохранные меры, а взаимосвязь экосистем и природных комплексов играет важную роль в обеспечении их устойчивости. Представленная в исследовании модель может помочь сохранить биоразнообразие, снизить антропогенное воздействие, устранить экологические барьеры и развивать соответствующие формы землепользования.
\end{abstract}

Ключевые слова: экологическая сеть, экологические коридоры, буферные зоны, экосистемы.

Для цитирования: Джабраилов Э.А. Модель экологической сети в Шахдагском национальном парке // Вестник Воронежского государственного университета. Серия: География. Геоэкология, 2021, № 2, c. 61-69. DOI: https://doi.org/10.17308/geo.2021.2/3449

(C) Джабраилов Э.А., 2021

ه Джабраилов Эмиль Акиф оглы, e-mail: emil.jabrayilov@gmail.com

Контент доступен под лицензией Creative Commons Attribution 4.0 License. 


\section{СПИСОК ЛИТЕРАТУРЫ}

1. Adriaensen F., Chardon J. P., De Blust G., Swinnen E., Villalba S., \& Gulinck H., et al. The application of «least cost» modelling as a functional landscape model // Landscape and Urban Planning, 2003, 64 (4), pp. 233-247. DOI: 10.1016/S0169-2046(02)00242-6.

2. Bennett A.F. Linkages in the landscape. The role of corridors and connectivity in wildlife conservation. IUCN, Gland, Switzerland and Cambridge, 1999, UK. x+254 pp.

3. Bennett G. and Mulongoy K. J. Review of Experience with Ecological Networks, Corridors and Buffer Zones. Secretariat of the Convention on Biological Diversity, Montreal, Technical Series, 2006, no. 23. 100 p.

4. Bennett G. and Wit P. The Development and Application of Ecological Networks: a Review of Proposals, Plans and Programmes. Amsterdam: AIDEnvironment, 2001. 137 p.

5. Bennett G. Integrating Biodiversity Conservation and Sustainable Use: Lessons Learned From Ecological Networks. IUCN, Gland, Switzerland, and Cambridge, 2004, UK. vi + 55 pp.

6. Carlson T.N. and Ripley D.A. On the Relation between NDVI, Fractional Vegetation Cover, and Leaf Area Index // Remote Sensing of Environment, 1997, 62 (3), pp. 241-252. DOI: 10.1016/S0034-4257(97)00104-1.

7. Chang S.C., Tu C.J. \& Chen H.Y. Ecological corridor in the urban area: case study in Kaohsiung City, Taiwan // Practice Periodical of Hazardous, Toxic, and Radioactive Waste Management, 2010, 14 (1), pp. 76-88. DOI: 10.1061/(ASCE)HZ.1944-8376.0000018.

8. Chen C.D., Meurk D.C., Ignatieva E.M., Stewart H.G. \& Wu S.J. Identifying and evaluating functional connectivity for building urban ecological networks // Acta Ecologica Sinica, 2015, 35 (19), pp. 18-35. DOI: $10.5846 /$ stxb201402160263.

9. Climenco V., Trombitki I., Andreev A. The Ecological Network: A way to the nature conservation in Moldova. BIOTICA-Ecological Society, Moldova, 2002.

10. Dataset: JAXA/METI ALOS PALSAR L1.0 (2007). Accessed through NASA's Alaska Satellite Facility Distributed Active Archive Center (accessed: Aug 05, 2020).

11. Drusch M., Del Bello U., Carlier S., Colin O., Fernandez V., Gascon F., ... \& Bargellini P. Sentinel-2: ESA's optical high-resolution mission for GMES operational services // Remote sensing of Environment, 2012, 120, pp. 25-36. DOI: 10.1016/j.rse.2011.11.026.

12. Gurrutxaga M, Lozano P.J., del Barrio G. GISbased approach for incorporating the connectivity of ecological networks into regional planning // Journal for Nature Conservation, 2010, 18 (4), pp. 318-326. DOI: 10.1016/j.jnc.2010.01.005.

Jabrayilov Emil Akif oghlu

Scientific researcher at the Institute of Geography, Azerbaijan National Academy of Sciences, Baku, Azerbaijan, ORCID: 0000-0001-9391-4319, e-mail: emil.jabrayilov@gmail.com
13. Гусев А.П. Изменения NDVI как индикатор динамики экологического состояния ландшафтов (на примере восточной части Полесской провинции) // Вестник ВГУ. Серия: География. Геоэкология, 2020, № 1, c. 101-107. DOI: 10.17308/geo.2020.1/2667.

14. Гаджиев Г.А., Рагимов В.А. Климатическая характеристика административных районов Азербайджанской ССР. Баку, 1977. 270 с. (на Азерб.).

15. Ибрагимов Т. Национальные парки Азербайджана. Баку, 2015. 336 с. (на Азерб.).

16. Jongman R.H.G., Kulvik M., \& Kristiansen I. European ecological networks and greenways // Landscape and Urban Planning, 2004, 68 (2-3), pp. 305-319. DOI: 10.1016/S0169-2046(03)00163-4.

17. Lee T.M., Jetz W. Future battlegrounds for conservation under global change // Proceedings of the Royal Society B: Biological Sciences, 275 (1640), pp. 12611270. DOI: 10.1098/rspb.2007.1732.

18. MacArthur R.H. and Wilson E. O. The Theory of Island Biogeography. Princeton University Press, 1967, vol.1. $215 \mathrm{p}$.

19. Мамедов Г.Ш., Халилов М. Ю. Леса Азербайджана. Баку, 2002. 472 с. (на Азерб.)

20. Martino D. Buffer Zones around Protected Areas: A Brief Literature Review // Electron. Green Journal, 2001, 1 (15), pp. 1-20.

21. Opdam P., Steingrover E. G., \& van Rooij S.A.M. Ecological networks: A spatial concept for multi-actor planning of sustainable landscapes // Landscape and Urban Planning, 2006, 75 (3-4), pp. 322-332. DOI: 10.1016/j. landurbplan.2005.02.015.

22. Pressey R. L., Cabeza M., Watts M.E., Cowling R. M., Wilson K.A. Conservation planning in a changing world // Trends in ecology \& evolution, 2007, 22 (11), pp. 583-592. DOI: 10.1016/j.tree.2007.10.001.

23. Родоман Б. Б. Поляризация ландшафта как средство сохранения биосферы и рекреационных ресурсов // Ресурсы, среда, расселение, 1974, с. 150-162.

24. Simenova V., Bos E., Jongman R., Zingstra H. Implementation of ecological networks in different socioeconomic contexts. Guiding principles based on experiences in Central and Eastern Europe. Wageningen, Alterra, 2009. 117 p.

\section{КОНФЛИКТ ИНТЕРЕСОВ}

Автор декларируют отсутствие явных и потенциальных конфликтов интересов, связанных с публикацией настоящей статьи.

Поступила в редакичию 01.03.2020 Принята к публикачии 28.05.2021

Джабраилов Эмиль Акиф оглы научный сотрудник Института Географии Национальной Академии Наук Азербайджана, г. Баку, Азербайджан, ORCID: 0000-0001-9391-4319, e-mail: emil.jabrayilov@gmail.com 